\title{
Concepts of disease in Ethiopia: from macro predator to microorganism
}

\author{
Melaku Tefera, \\ College of Veterinary Medicine, Haramaya University, P.O.Box 144. Haramaya, Ethiopia. Tel. \\ 251-091472/251-025-5530334.melaku22@yahoo.com
}

\begin{abstract}
Knowledge and understanding of concepts of disease is important in the delivery of veterinary services and how students learn in veterinary medicine. This study analyzes the conceptual and philosophical basis for epidemiologic advances and changing paradigms in Ethiopia from the historical and modern viewpoint of disease concepts. Our finding shows that, there existed a multiple of concepts of disease, in an interface of science and spirituality namely: predator, evil spirit, religious and biomedical; in chronology. Despite these concepts were diametrically opposing each other, the general public had not reject old concepts, simply all were amalgamated. Hence, Ethiopian farmers seek assistance from sorcery, traditional healers, priests and veterinary doctors. In traditional Ethiopian disease concept, major cause of disease was supposed evil spirit, which originated from metaphysics and cosmological belief. A similar crosscutting of concepts were observed among veterinary students and professionals. We suggest if an antagonistic relationship between science and religion is perceived by student the learning outcome will be superficial and will suppress further scientific progress. While a symbiotic relationship between science and religion will alleviate the apathy.
\end{abstract}

Keywords: Claude Bourgelat, Ethno-veterinary, philosophy of science, the germ theory, Star and crescent, traditional medicine, veterinary medicine.

http://dx.doi.org/10.4314/evj.v16i1.6

\section{Introduction}

The mission of the veterinary curriculum in Ethiopia is to impart knowledge, skill and attitude. However, the curriculum brings less attitude change due to strong cultural attachment and religion (Melaku Tefera, 1995). Understanding student's conceptual ecology, the perception in science and spirituality as epistemological systems is a key factor in how student learn veterinary medicine (Cobern, 1996). This entails, among other things, an understanding of the nature of scientific knowledge and the ways in which students conceive scientific knowledge in relation to their other ways of understanding the world. 
As stated by Shipman, et al., (2002), a person sitting in a science classroom is not just a science student; she or he is a thinking human being who sees the world in terms of a variety of other contexts.

The concept of disease has changed with dominant conceptions of medicine in different epochs (Hofmann, 2001). In the developed world there was conceptual revolution from Evil Spirit Theory of disease to Hippocratic Humourism Theory and Pasteur's Germ Theory in 1860 (Worboys, 200 ). The year 2011 marked the $250^{\text {th }}$ anniversary of the foundation of veterinary education by Claude Bourgelat in Lyon France. During this interval you will notice as new discoveries emerge and are understood, the concept of disease changes (André and DDay, 2005). Nevertheless the definition, meaning and description almost remain the same (Gunnarsson, 2006).

Ethiopia offers an excellent setting for examining different concepts of disease, because the influence of the Germ Theory is quite recent, modern secular education began 50 years ago (Melaku Tefera, 2011). Most medical practices are traditional (WHO, 2008). Ethiopian traditional medicine considers almost all illness as sprit caused and hence the treatments involve performing rituals, sprit mediation, prayers, and herbal treatments (Bahiru, 2005).

The objective of this study was to assess changes in concepts of disease that occurred in Ethiopia and the impact of modern veterinary education on student's perception and learning outcomes.

\section{Materials and Methods}

Participant observation method was used. The general approach was to extract subjective statements from individuals, within a disease domain, about concepts and relations among these concepts. Cognitive mapping was used to show causal relationship, (Ottmann, 2005). Individual interviews were also employed. Traditional healer's bonesetter, herbalists, diviners religious leaders veterinarians and students were involved. Additional data about traditional healers was used from Tefera, (2001). The archeological investigations were according Tefera, (2004). The cave painting study and visual image interpretations were part of Tefera and D'Andrea, (2006). Additional image were collected and documented. 


\section{Results}

The archeological survey in northern Ethiopia revealed several cave paintings one of the painting was found useful for this study which is shown on Figure 1, shows early animal husbandry. This rock shelter painting is situated in GuloMekeda at a place called Amba-Fekada around $200 \mathrm{~km}$ from Mekelle town. One can see anthropomorphic, zoomorphic and geometric figures. The general theme of the rock panel is feline attacking yoked plowing cattle and people defending with spear bow and arrow.

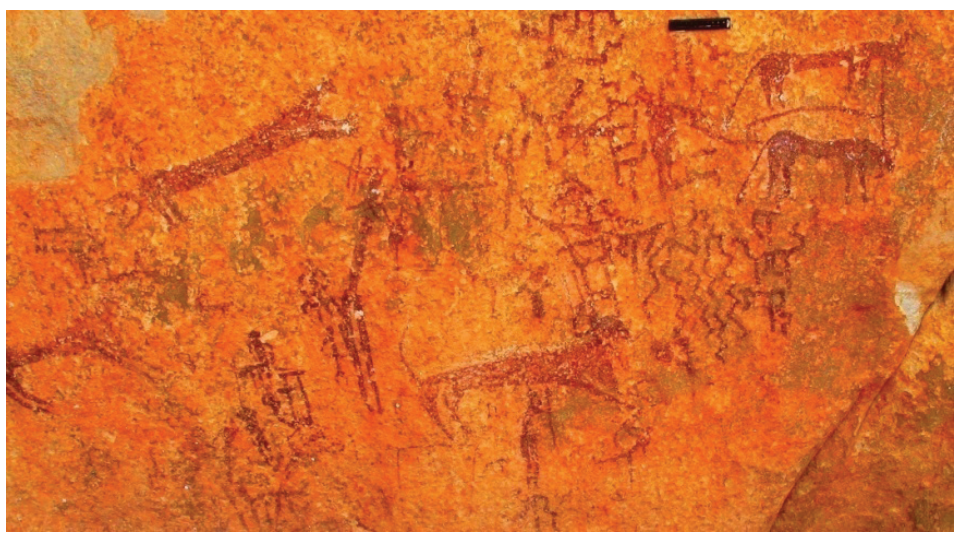

Figure 1. Amba- Fekada hunting and ploughing cave painting rock pamnnel

Another archeological finding was rock art carving shown on Fig.2a, this standing 22 meter

a monolith (Obelisk number 3). Its significance was worship symbol. Figure $2 \mathrm{~b}$ was the the base plate attached to the obelisk number 3 . Sacrificial table was carved in to it. 


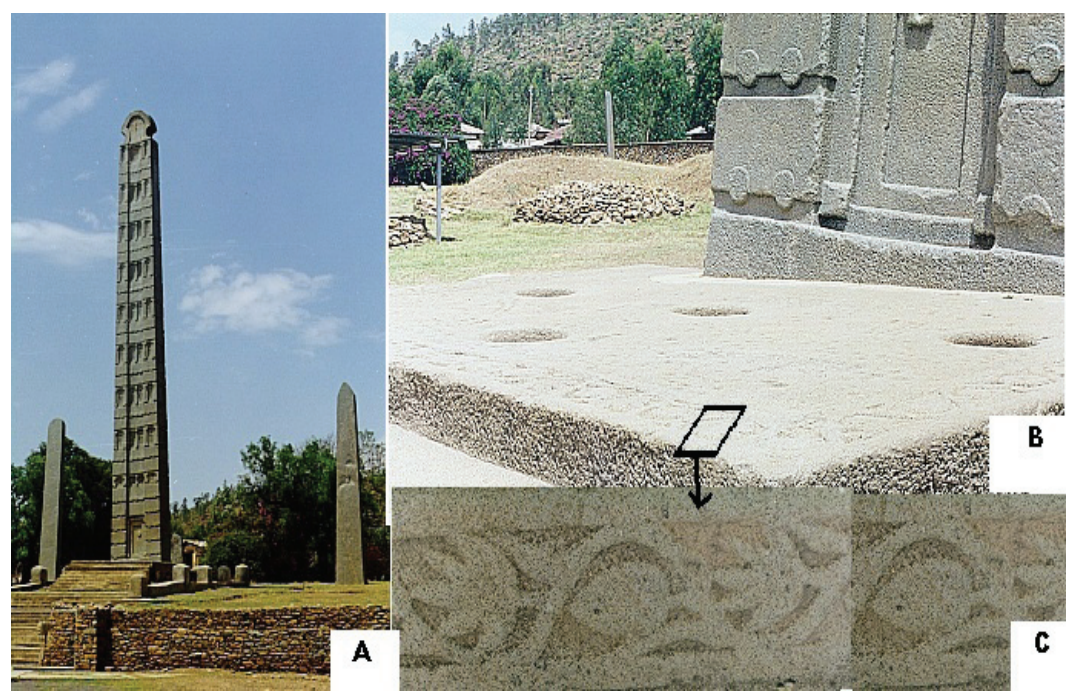

Figure 2: Axumite rock art evidence evedence of religious symbolism

The vessels which are seen in the picture as black circles are evedense of sucrifice were given to gods. The margins of the baseplate were were decorated with a vine design of bass relief curving indicative of an altar.

Two different Axumite coins are depicted on Figure 3. On the top border of fig 3a, shows the star and the cresent moon, Figure $3 \mathrm{~b}$ depicts cross and the emmer wheat. Figure 4, shows healing scrolls, a combination of Christian religious artifact and magical invocation to heal someone who's gravely ill and for animals as well. They're made out of parchment from a single goat or lamb, cut to be exactly as tall as the sick person. Ideally the sick person is also bathed in the blood of the goat or lamb from which the parchment is taken; thus the parchment scroll is standing in for that person. The scroll is then covered with religious iconography and texts in red and black ink. Figure 4ac, depicts evil spirit attacking and Holy Spirit protecting, while oxen were in peak performance. The angel in the picture is a protecting shield. 

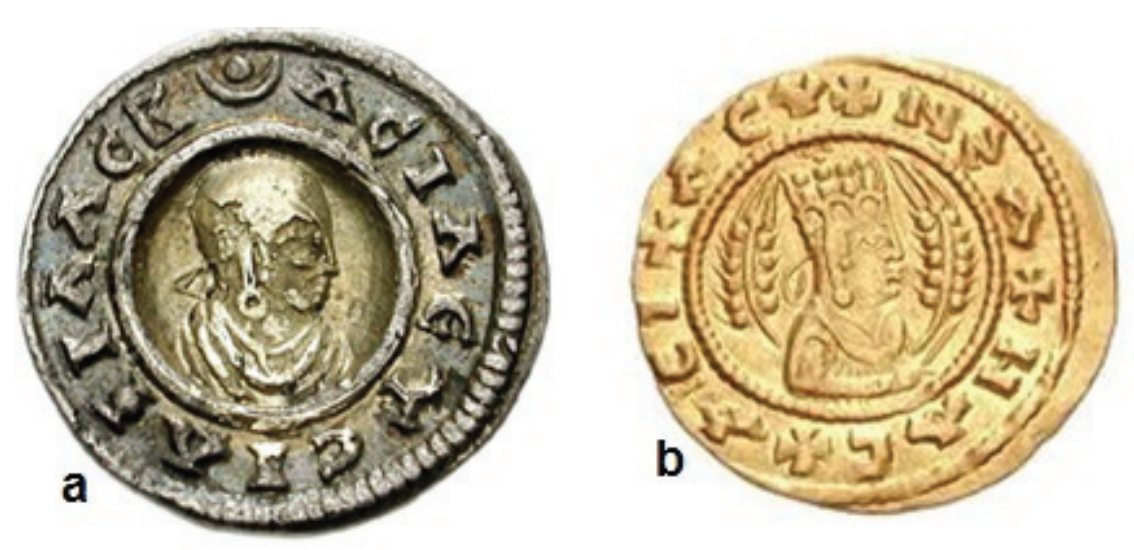

Figure 3: Axumite coins depicting transition of belifs

On Figure 4d, the drawing represents an Ethiopian art explaining effect of evil eye. The evil eye is shown disguised in some form of animal a hyena. Respondents to an interview explained that, the most important times for evil eye attack include: meal times, illness, pregnancy, cattle rearing and crop growing. Figure 4e, is a therapeutic talisman which was intended to work on the person who own this magic scroll. The patient, shown clothed in what the clerics call "garments of grace," on Figure 4f, protects someone from evil spirit, when the patient sees it, he become frightened and cries out, and then the demon leaves him--so say the clerics. Properly speaking, it isn't actually the patient who sees the image in this way but the spirit who lives in him, or who is attacking him. Figure $4 \mathrm{~g}$-h shows Ethiopian 

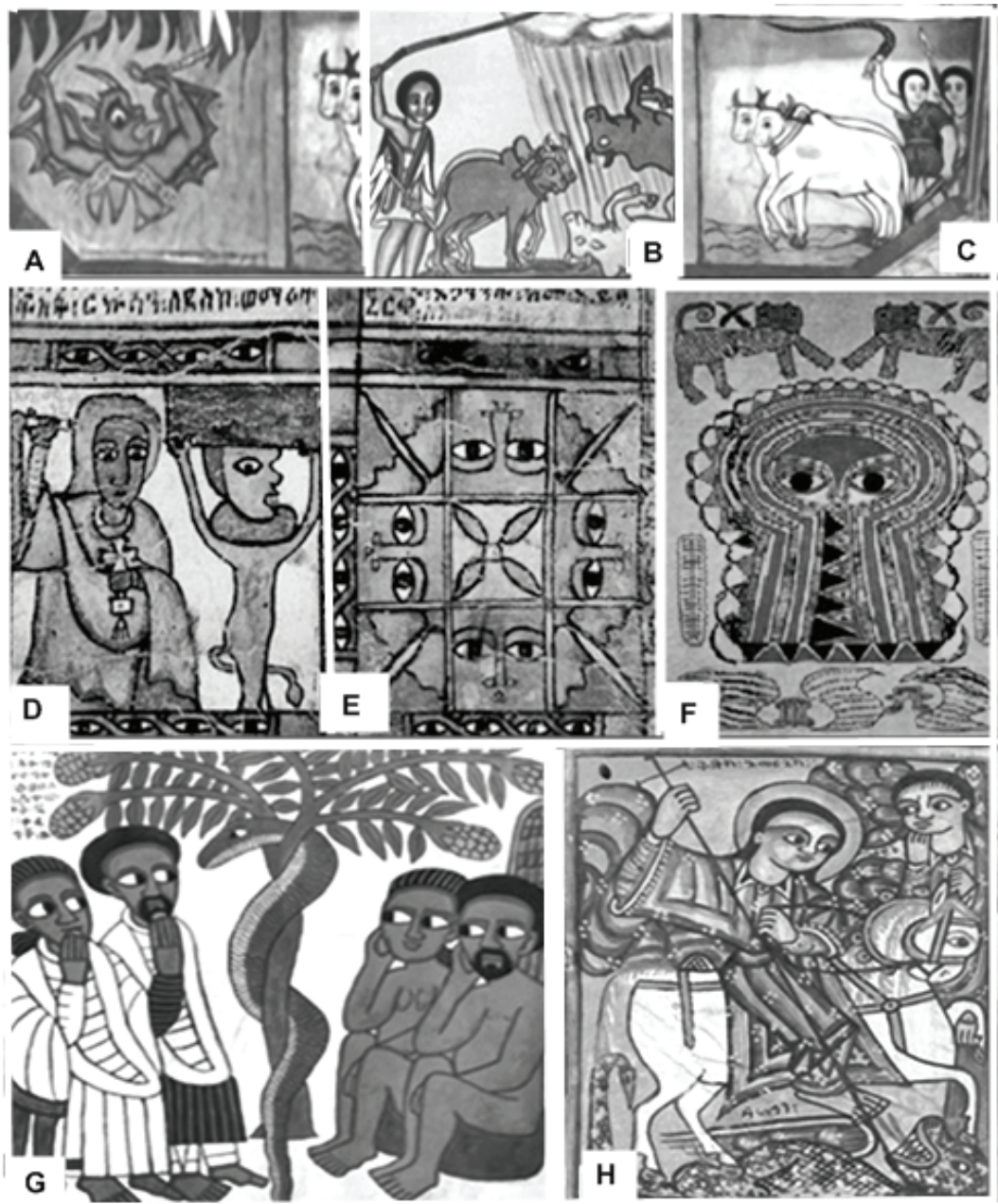

Figure 4: Ethiopian healing images, protective magicscroll and talisman

Orthodox painting showing the Garden of Aden and Saint George killing a dragon which is symbol of evil or disease a punishment from God for not fulfilling Christian obligations.

A concept map of theories and relationship between the cause process symptoms and treatment is depicted on Figure 5. as it is indicated, there were at least 4 clsssified concepts of disease causations prevailing in the Ethiopian public. 
The classification had an overlap due to amalgamation of concepts like religion, magic, herbalism and veterinary .A pair wise choices is shown on Table 1.

Table 1. Pair wise choice of types Animals therapies and conjugations

\begin{tabular}{lllllll}
\hline $\begin{array}{l}\text { Types of healing } \\
\text { consulted }\end{array}$ & Religion & Superstition & Herbalism & Veterinary & Score & Rank \\
\hline Religion & & 2 & 3 & 4 & 9 & 3 \\
$\begin{array}{l}\text { Superstition } \\
\text { Herbalism }\end{array}$ & & & 4 & 1 & 5 & 2 \\
$\begin{array}{l}\text { Veterinary } \\
\text { Rank }\end{array}$ & 1 & 4 & & 4 & 4 & 1 \\
\hline
\end{tabular}

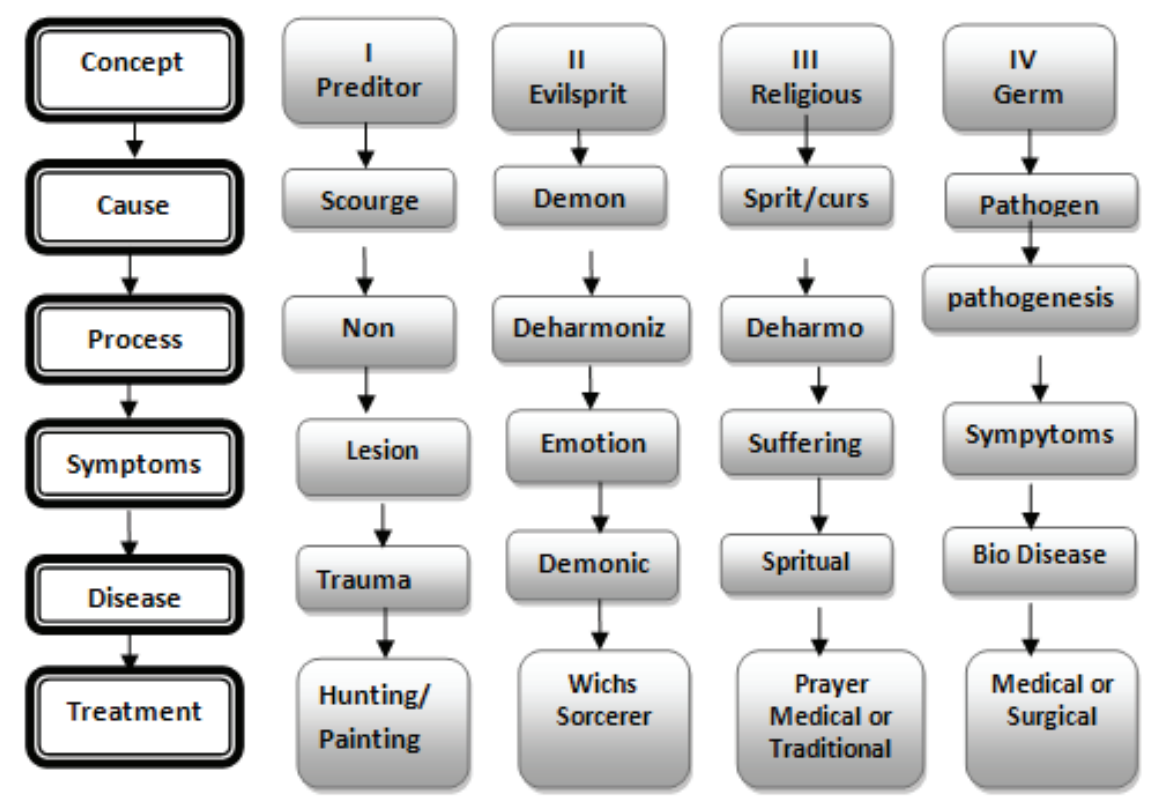

Figure 5: Concept map of disease in Ethiopia

\section{Discussion}

The Amba-Fekada rock panel indicates that an agricultural society existed and this was sufficient to conclude that the time was Neolithic. The presence 
of farm animals excludes Paleolithic. The spear indicates that an aspect of metallic dimension it indicates that the age is

rather late in a time when agriculture was well developed. But some style characteristic indicates that the panel of Amba-Fekada painting is not recent (Graziosi, 1964).

The oxen which are yoked to the plough are hump less. This is a species that is not related to zebu which was introduced to the country relatively recently cording to Epistein, (1971) around 4500 BP migratory people introduced hump less short horn cattle in East Africa. The theme of the panel was macropreditor as livestock scourge probably during that era disease due to macroparasites, such as tick lice, flea, and mosquito big enough to be seen with naked eye might have not been noticed.

Both animal bones and stauet were discovered below the obelisk of Axum, indicative of belief in life after death (Phillipson, 1993). During that era Axumites were beliving in Astar

( the sun god) and Almagha (the moon god). The Axumite coins illustrating the importance of agriculture. The cross, star and moon and cresent on the coins depict religious symbolism. The later belong to $350 \mathrm{BC}$, pre cristian era ( Munro-Hay, 1984 ) indicate that religious transformation has occurred and the importance of such religion in the daily life of the people.

Most Ethiopians belive in evil eye ( $b u d a)$. It is interesting that periods associated with fecundity and multiplication are so dangerous; it may be possible that the body is somehow weakened because most of the energy is being diverted into the promotion of growth both in the fields and in the womb, and is thus especially vulnerable to attack ( Finneran, 2003).

The sacrificial vessels carved into the obelisks and religious symbols on the coins proof such transformation and the beginning of the concepts of Evil Spirit Theory. In Ethiopia it is common to get treatment from spiritual people. The treatments used by priests are mainly prayer, holy water and holy ash, mineral soil. Another group of spiritual healers are wizards and the Debteras they are the most feared by the public as they can inflict evil upon individuals and their properties they are a sort of religio- magic practitioners (Mercier, 1979). All magic scroll and talisman are made by this people. They also practice herbalism most of the time they do not tell the medicinal plants until they inherit it to someone upon their retirement. In traditional African medicine 
diagnosis and treatments are beyond the causative agent (Chavunduka, 1999) by inquiring a step deeper into it so they create endless questions beyond the cause or about circumstances in which the disease has occurred on infinity mind of view. There are two principal options open to us if something is to be actual then we can either maintain that it must be finite or that can be infinite (Chapman, 1994). Actual things must be determinate, but it is not clear whether infinite things are. Infinite actually can neither be particular nor an attribute of a particular thing (Thompson, 2007).Thus in traditional medicines there are infinite etiologies and infinite treatments.

It is logical to assume at the beginning mankind was to associated illness with the macro-predators and later on macroparasites. As human beings start to think beyond their horizon they came across with sprits designating for a phenomenon that is beyond human understanding. Modern theory of disease emanated from Hippocrates naturalistic approach to medicine that contrasted sharply with religious views that preceded him (Packer, 2003). He rejected the previous casual network or concept map. The shift from the humoral to the germ theory of disease that required a conceptual revolution: the old conceptual and explanatory system was replaced by radically different one (Thagard, 1996). With the invention of a microscope the role of microorganisms in causing disease was deciphered. And lately viruses and prion causing disease was understood. In contrast the development in the $20^{\text {th }}$ century of concepts of genetic, nutritional, immunological and metabolic diseases were relatively conservative extensions of nineteenth century ideas, new causes were introduced without denying that the germ theory because it was right about the causes of disease to which it had been applied. Change of concept is then be conservative or non conservative (Thagard, 1996). Our results show , in Ethiopia, that most of the change of concept are conservative as non of the previous bailiffs rejected despite the concepts are diametrically opposing each other as a result many people seek different line of treatments, the quest for shifting therapies is born out of frustration and dissatisfaction. Labeling a disease un curable is a powerful source of frustration and questioning. Long term chronic ill health, in particular.

In conclusion knowledge and understanding concept of disease is a vital prerequisite to prevention of diseases, delivery of animal health and determine the needs of veterinary services in the country and to enable efficient programme and planning. Also understanding student's conceptual ecology is a determining factor in the learning process. Student assume three different views on the relationship between science and spirituality 1) antagonistic 2) 
mutually supporting and 3) different domains with no relationship .All theories of health and illness serve to create a context of meaning within which the student can make his professional judgment. If an antagonistic relationship between science and religion is perceived by student the learning outcome will be superficial, curiosity will be suppressed and further scientific progress will be hindered. While symbiotic relationship between science and religion alleviates the apathy.

\section{References}

André J and _Day, T. 2005. The effect of disease life history on the evolutionary emergence of novel pathogens. The Royal Society of biological Science .doi: 10.1098/ rspb.2005.3170 Proc. R. Soc. B 22 September 2005 vol. 272 no. 1575 1949-1956

Bahiru, W. 2005. Impacts of Urbanization on the Traditional Medicine of Ethiopia. Anthropologist, 8(1): 43-52

Chapman, J. 1994. The Knowledge of Good and Evil. http://www.hyperthot. com/111_toc.htm. Accessed on Nov, 2010.

Chavunduka L.1999. Christianity, African Religion and African Medicine. World council of churches Religion $\backslash$ Christianity, African Religion and African Medicine. mht

Cobern, W. W. (1996). Worldview theory and conceptual change in science education. Science Education, 80(5), 579-610.

Dekkers W and Gordijn B. 2010. Conceptual analysis and empirical research in medical philosophy and medical ethics Med Health Care and Philos. (2010) 13:1-2. DOI 10.1007/s11019-009-9225-8

Epstein H. 1971. The origin of domestic animals of Africa. Vol. I. Africana Publishing Cooperation, New York, USA.

Finneran, N. 2003. Evil eye belief in Ethiopia and the magical symbolism of iron working' Folklore 114/3: 427-436

Graziosi, P.1964. New discoveries of rock paintings in Ethiopia Part I. Antiquity, XXXVIII, 91-103

Gunnarsson, S. 2006. The conceptualization of health and disease in veterinary medicine Acta Vet Scand. 2006; 47(1): 71. Published online 2006 November 7. doi: 10.1186/1751-0147-47-71

Hofmann, B. 2001. Complexity of the concept of disease as shown through rival theoretical frameworks. Theoretical Medicine. 22:211-236 
Kobischanove, YM. 1979. Axum J.W. Michels, ed., L.T. Kapitanoff, transl., Pennsylvania State University Press, University park, PA, USA.

Mercier, J. 1979 Jacques, Ethiopian Magic Scrolls, G. Braziller, New York

Munro-Hay, S. 1984. The coinage of Axum, Manohar, Delhi

Ottmann, J .2005. The Medicine Wheel as a Concept Map. In Richard Dagan, Intraspec. ca http://intraspec.ca/cogmap.php accessed December 2010

Parker, R. 2003. The Hippocratic Humoural Theory A Proper Philosophical and Historical Context - The Rational Argumentator. Issue XIV -Objective Medicine at http://www.objectivemedicine.org

Phillipson, D. 1993. The antiquity of cultivation and herding in Ethiopia. In: T.shaw, P Sinclair, B Andah and A. Okpoko (eds), The archeology of Africa; Food metals and towns (One world archaeology 20, Roulledge, New York

Shipman, H. L., Brickhouse, N. W., Dagher, Z., \& Letts, W. J. 2002. Changes in student views of religion and science in a college astronomy course. Science Education, 86(4), 526-547.

Tefera, M and D'Andrea, C.2006. Analysis of zoomorphic painting in seven rock shelters in Northern Ethiopia. In: $18^{\text {th }}$ biennial conference, society of Africanist archeologist (SAFA) 23-26 June 2006. University of Calgary, Alberta, Canada. (Abstracts)

Tefera, M. and Gebreab, F. 2001 A study on the productivity and diseases of camel in Eastern Ethiopia. Tropical Animal Health and Production 33: 265-274.

Tefera, M. 1996. The dogma of food consumption and the role of biology education in Ethiopia. In proceeding of Biological Society of Ethiopia. (Abstract)

Tefera, M. 2004. Recent evidence of animal exploitation in the Axumite epoch, $1^{\text {st }}-5^{\text {th }}$ century AD. Tropical Animal Health and Production. 6:105-116

Thagard, P. 1996. The concept of disease: Structure and change. Communication and Cognition, 29: 445 - 47855(4):189-208.

Thompson, D. 2007. Putting the Fire in the Equations; generating multilevel dynamical processes in Physics and Psychology. www.GenerativeScience.org

WHO. 2008. Traditional medicine Fact sheet $\mathrm{N}^{\circ} 134$.

Worboys, M. 2000. Spreading Germs: Disease theories and medical practice in Britain 1865-1900.Cabridge University Press. 208

Ethiop. Vet. J., 2012, 16 (1), 71-81 
